\title{
Adaptation Strategy of Seaweed Cultivation to Face the Climate Change (Case Study in Segoro Anakan Bay Ngadirojo, Pacitan)
}

\author{
Syahrial Nur Amri' ${ }^{1}$, Taslim Arifin \\ Pusat Penelitian dan Pengembangan Sumberdaya Laut dan Pesisir, Balitbang KP \\ ${ }^{1}$ Corresponding author (email: sn_amri@yahoo.co.id)
}

\begin{abstract}
The damage of coastal ecosystems are no longer dominated by human activity, but the condition of global climate change were also influenced. Climate change impact on the environment influencing the coastal management paradigm. This study emphasizes on how to develop a adaptation strategy of coastal zone management due to the impact of climate change through remote sensing approach, Geographic Information Systems (GIS), and adaptation strategies analysis. Location of research conducted in the Region of Segoro Anakan Bay, District Ngadirojo Pacitan. The results showed the impact of climate change is affecting the area and production of seaweed culture in the form of tectonic conditions aggravated by silting waters. To combat the effects of climate change, the adaptation scenario is implemented to intensification and extensification of land use, alternative livelihoods, and minawisata.
\end{abstract}

Keywords: adaptation, seaweed, climate change, Segoro Anakan Bay

\begin{abstract}
Abstrak
Kerusakan ekosistem pesisir tidak lagi didominasi oleh aktifitas manusia, tetapi kondisi perubahan iklim global juga turut mempengaruhinya. Dampak perubahan iklim terhadap lingkungan memberi pengaruh terhadap paradigma pengelolaan wilayah pesisir. Penelitian ini menekankan pada bagaimana menyusun strategi adaptasi pengelolaan wilayah pesisir akibat dampak perubahan iklim melalui pendekatan Penginderaan Jauh dan analisis strategi adaptasi. Lokasi penelitian dilaksanakan di Wilayah Perairan Teluk Segoro Anakan, Kecamatan Ngadirojo Kabupaten Pacitan. Hasil penelitian menunjukkan dampak perubahan iklim mempengaruhi luas area dan produksi budidaya rumput laut yang diperparah oleh kondisi tektonik berupa pendangkalan perairan. Untuk mengatasi dampak perubahan iklim tersebut, maka skenario adaptasi yang dapat dimplementasikanadalah intensifikasi dan ekstensifikasi lahan, alih fungsi lahan, mata pencaharian alternatif, dan minawisata.
\end{abstract}

Kata kunci: adaptasi, rumput laut, perubahan iklim, teluk Segoro Anakan

\section{Introduction}

Climate change which is characterized by extreme weather, rising of sea level and temperature, shifting seasons and rainfall intensity, affects the coastal ecosystem and human life. The influence of climate change are evident, particularly for the poorest people whose livelihoods depend on coastal resources (Moediarta and Stalker, 2007). Related to society, climate change affecting water availability has an impact on livelihoods, food stability and health (Adger et al., 2009).

The main impacts of climate change on marine aquaculture area areinundation, loss of economic assets and fisheryinfrastructure, erosion and destruction of cultivated landsand biodiversity in the coastal areas. Climate change will greatly affect physiology and behavior of individuals, populations and communities. The extreme conditions such as the rising of water temperature, the low dissolved oxygen concentration and water $\mathrm{pH}$ can cause death to the fish as well (Roessig et al., 2004).

One identification technique of impacts ofclimate change in coastal areas is to apply remote sensing technology. Remote sensing technique is a technique to obtain information of earth objects using electromagnetic waves without any direct contacts with the objects. It basically uses spectral patterns derived 
from the characteristics of each object (land cover). By using multi temporal of data image satellite, it will indicate the type of land cover change caused both by a decrease in sea level and removal of land. The identification process will provide spatial information about what sectors are affected; environment, resources, and anthropogenic. Its result will be a basis in preparing the analysis of adaptation strategies.

\section{Research Method}

\section{Research Location and Date}

This research was conducted in Segoro Anakan Bay, Sidomulyo Village, Ngadirojo District, Pacitan Regency (Figure 1), while data collection was conducted in AprilNovember, 2011.

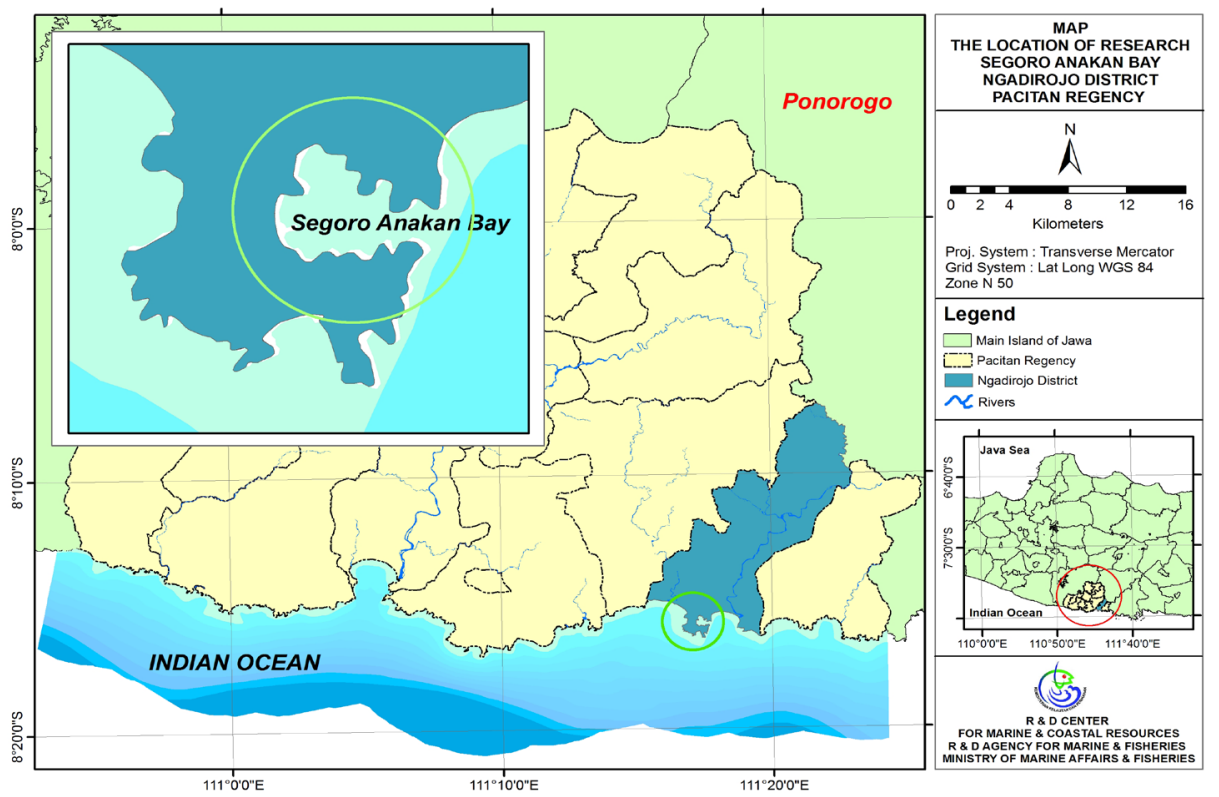

Figure 1. Map of research location.

\section{Data Source and Analysis}

Data Source of this research using Landsat 7 ETM+ satellite imagery acquisition in 2002 and 2011. Landsat 7 ETM+ has six $30 \mathrm{~m}$ bands that cover the visible near infrared and shortwave infrared regions of the electromagnetic spectrum, one $15 \mathrm{~m}$ panchromatic band, and one $60 \mathrm{~m}$ thermal infrared band. Hereinafter are compared with field survey data, interviews, and literature background. Meanwhile, the data analysis covers several stages:

a. Image Geometric Correction; Geometric correction is a process of data transformation from one grid system using a geometric transformation (Jaya, 2009). One objective of geometry correction is to have a rectificationso that the image has coordinate properties according to geographic coordinates (Purwadhi, 2001). In this study the geometry correction process is performed on Landsat-7 TM. Geometry correction was done through the creation of ground control points (GCP) which compared the GCP positions of Landsat-7 ETM+ to the coordinates of the field condition.

b. Image Processing; Conducted through several stages; image enhancement, the making of RGB image, the selection of the bestRGB image, the classification of K-Means, the determination of training set, the classification of Maximum Likelihood classification and accuracy evaluation (Schowengerdt, 2007; Lillesand and Kiefer 1990).

c. Data Collection; Identify the impacts of climate change through observations and direct measurements in the field as part of the process of field check, then combine it with the results of the interview and 
literature background. This identification includes;identification of the impacts on environment and resources as well as the impact on socioeconomic conditions of coastal communities. The results of the data input in phases 1 and 2 was the database to process using Geographical Information System (GIS).

d. Analysis of strategies; analysis ofadaptation startegy policy is a qualitative analysis to find a formula of adaptation to climate change impacts

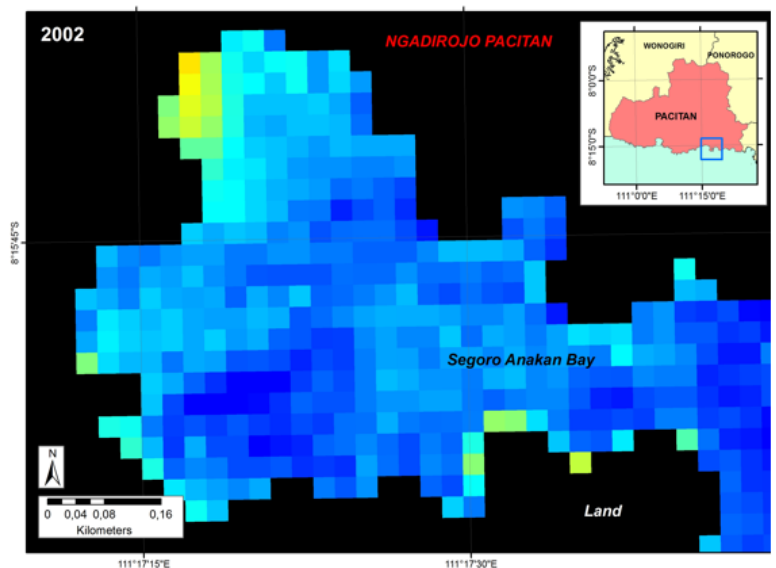

Figure 2. The Condition Of Water Body of Segoro Anakan Bay on 2002 Base On Lysenga Algorithm.

The interpretation of satellite imagery figures out the occurrence of the land cover type changes along Tawang Beach, Segoro Anakan Bay, from 2002 to 2011. The 2002 and 2011 imagery revealed a reflectance anomaly demonstrating real distinctions between two land cover objects (The water column and the substrates of the coastal bottom waters marked using white circle). In 2001, the condition of the object (white circle) still in the form of water. But, in 2011, in the same place, the condition of the object (white circle) had changed. Up to now, the condition of bottom water along Tawang Beach, Segoro Anakan through the management and utilization of coastal areasin effective, optimal, integrated, and sustainable ways.

\section{Result and Discussions}

The satellite imagery transformation makes use of Lysenga Algorithm to extract the reflectance of the condition of water column. The continuation interpretation, we will indicate changes in land cover types resulted from both sea-level subsidence and land uplift (Figure 2 and 3).

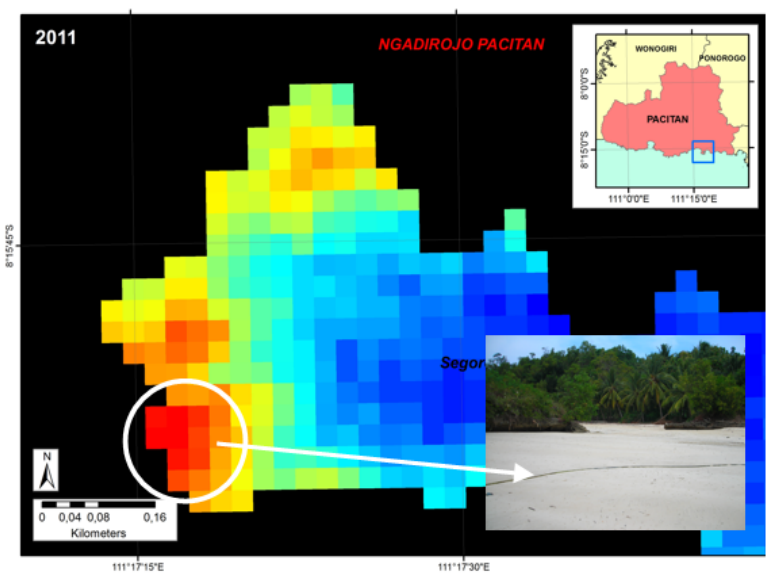

Figure 3. The Condition Of Water Body of Segoro Anakan Bay on 2011 Base On Lysenga Algorithm.

Bay is still inundated during the high tide, but the intensity of the inundation does not take a long period of time (Figure 4). This condition causes the seaweeds on this spot to be unable to be optimally harvested. Extreme output decline occurred in 2009 to 2011. In reference to the data taken from Marine and Fisheries Agency (MFA) of Pacitan Regency, seaweed output in Segoro Anakan Bay decreased from 35,831 ton in 2009 to 1,032 ton in 2011 . Moreover, at the beginning of January to June 2011, based on survey results, production failure occurred in affected areas. 

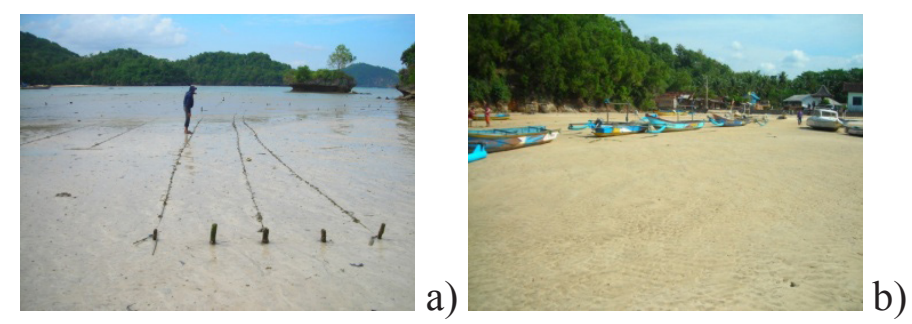

Figure 4. Conditionof unproductive seaweed land in the region (a), raising of the land face causes the boat mooring distance is farther away from TPI Tawang, Sidomulyo Village, Ngadirojo District (b).

From the modeling results reported by Jadmiko (2011), the regional climate of monthly rainfall (1985-2009) in Pacitan Regency committed to change from $-37.95 \%$ to $45.25 \%$, while the increase of the air temperature ranged from 0.48 to $2.55^{\circ} \mathrm{C}$. Extreme rainfall analysis also revealed that the opportunity and frequency of extreme rainfall in Pacitan Regency were increasing. The high temper of the sea level resulting in prolonged rainy season in 2010 was estimated as the impact of global warming; it occurred due to the phenomenon of the Earth's rising temperature as the result of the accumulation of greenhouse gases in the atmosphere holding the solar heat energy in the Earth's surface.

According to the Center of Volcanology and Geohazard Mitigation (PVMBG) in Hertanto (2011), Pacitan area is an active fault line (faulting) which is in line with the river of GrinduluPacitan extending from the south sea to the upper course in Bandar sub-district of Pacitan. Grindulu faulting is a fault line of continental plates forming Java Island, stretching in five sub-districts in Pacitan regency, comprising Bandar, Nawangan, Punung, Arjosari, and Donorojo sub-districts. The erratic climate conditions in 2009 to 2011 highly influenced the economic condition of the local community, particularly those working in areas of agriculture, fisheries, and sea cultivation. Seaweed cultivation suffered from harvest failure due to the continuous rain resulting in low salinity, high turbidity, tectonic siltation, and sea surface temperature rise. The natural phenomena due to the climate change will affect coastal community's pattern of life. If it is not anticipated soon, surely it will lead to social insecurity. The government and society should find out forms of adaptation to cope with the impacts of climate change using top down and bottom up methods. The aforementioned adaptation forms need to be arranged in the form of integrative and sustainable management scenario.

\section{Adaptation Strategies to Cope with the Impacts of Climate Change}

In reference to IPCC (2007), adaptation is defined as the adjustment of nature or human to either actual or predicted climate conditions as well as the impacts that may arise. They adapt either to reduce vulnerability or to increase resilience for the purpose of anticipating the predicted changes (anticipative adaptation) (Adger et al. 2007).

The adaptation methods conducted are the combination of top-down and bottom up analysis, in which in the top-down analysis the model and the scenario analysis are developed, while in the bottom-up analysis vulnerability approach is applied by considering the ability of the society and the developed local wisdom to encounter the impacts of climate change. Human activities influence the climate change by altering ecosystem distribution and its association, for instance, energy flux and the evaporation of water, gases, and particles. In the landscape scale, land cover (Figure 5) gives influence to the energy pattern and mass flux (Dale, 1997). Some of the scenarios include: 


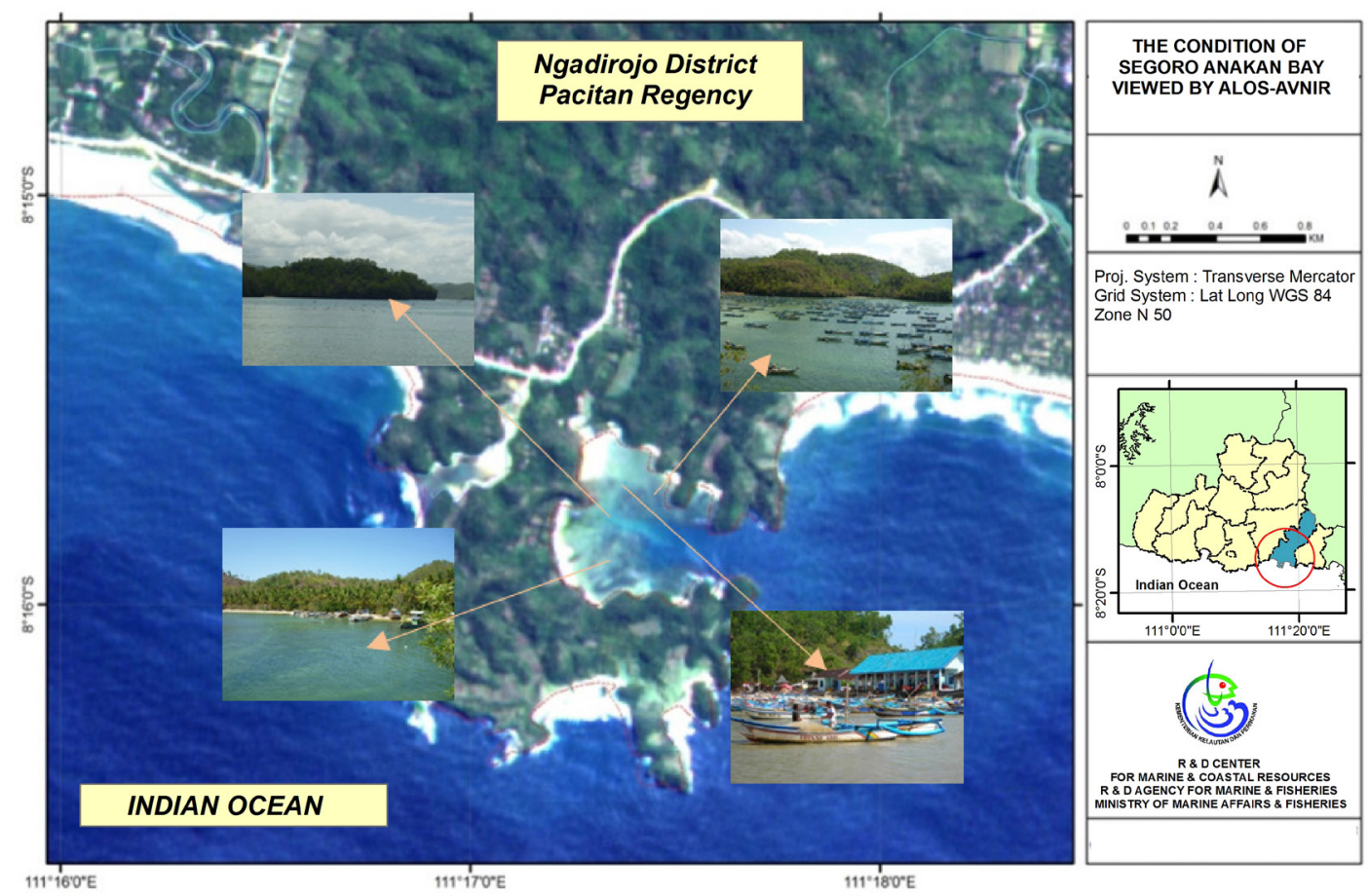

Figure 5. Land use and land covering in SegoroAnakanbay, Sidomulyo village,Ngadirojo district,Pacitan regency.

Adaptation Scenario 1: Intensification and Extensification

Due to the climate change, the farming area of sea cultivation in the research location is getting narrower (Figure 6). The basic substrates forming Segoro Anakan coast are coral reefs with open wave and current. The condition leads to difficulties in finding appropriate locations to develop seaweed cultivation; this condition also causes coastal community in Pacitan to rely more on the existence of natural seaweeds which are harvested when low tide. According to Arifin et al (2014), the requirements of the environmental condition for seaweed cultivation are materials of sandy bottom water, coral and sea grass; the current speed ranges from $20-30 \mathrm{~cm} / \mathrm{second}$, and the wave height is $0-15 \mathrm{~cm}$.

Regarding the condition, a special adaptation is required, and therefore seaweeds can still be continuously cultivated. Forms of adaptation a fisherman can apply are land extensification and intensification. Land extensification is related to area expansion, but this method definitely requires more complicated cultivation techniques since the extensification in SegoroAnakanbay is directed to high seas of which oceanographic condition will be more extreme.
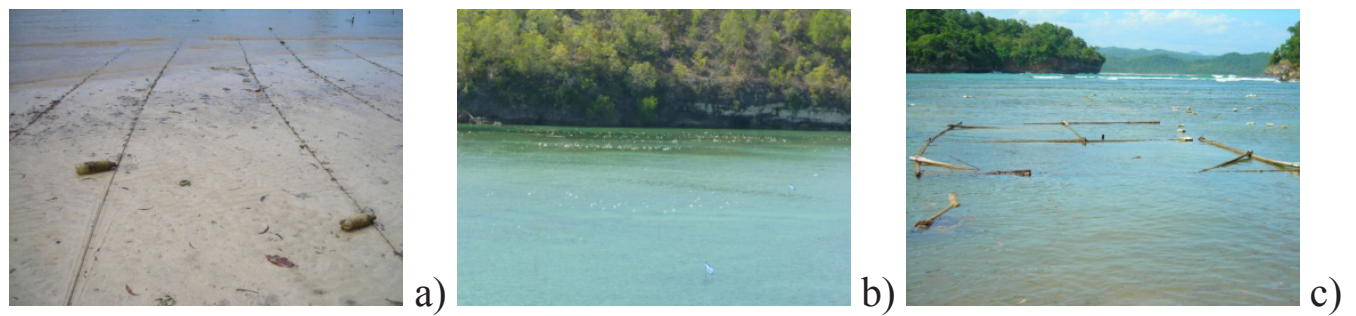

Figure 6. The first is seaweed cultivation methods with freelance basis. This system is placed near the affected coast (a), The second is seaweed cultivation with floating method (long line).This system is placed in the middle of the bay (b). The third is seaweed cultivation with floating raft method.This method is placed around the mouth of the bay (c). 
Seed spreader engineering is required to accommodate the extreme condition. The consequence of extensification pattern is area extension. This implies that new space utilization is needed. The most important thing to concern is the location of corridor and core zones. The former deals with fishermen's boat traffics. Meanwhile, the latter is buffer zone or zone of ecosystem preservation which can guarantee availability of germplasm for fisheries in local area of waters (Figure 7).
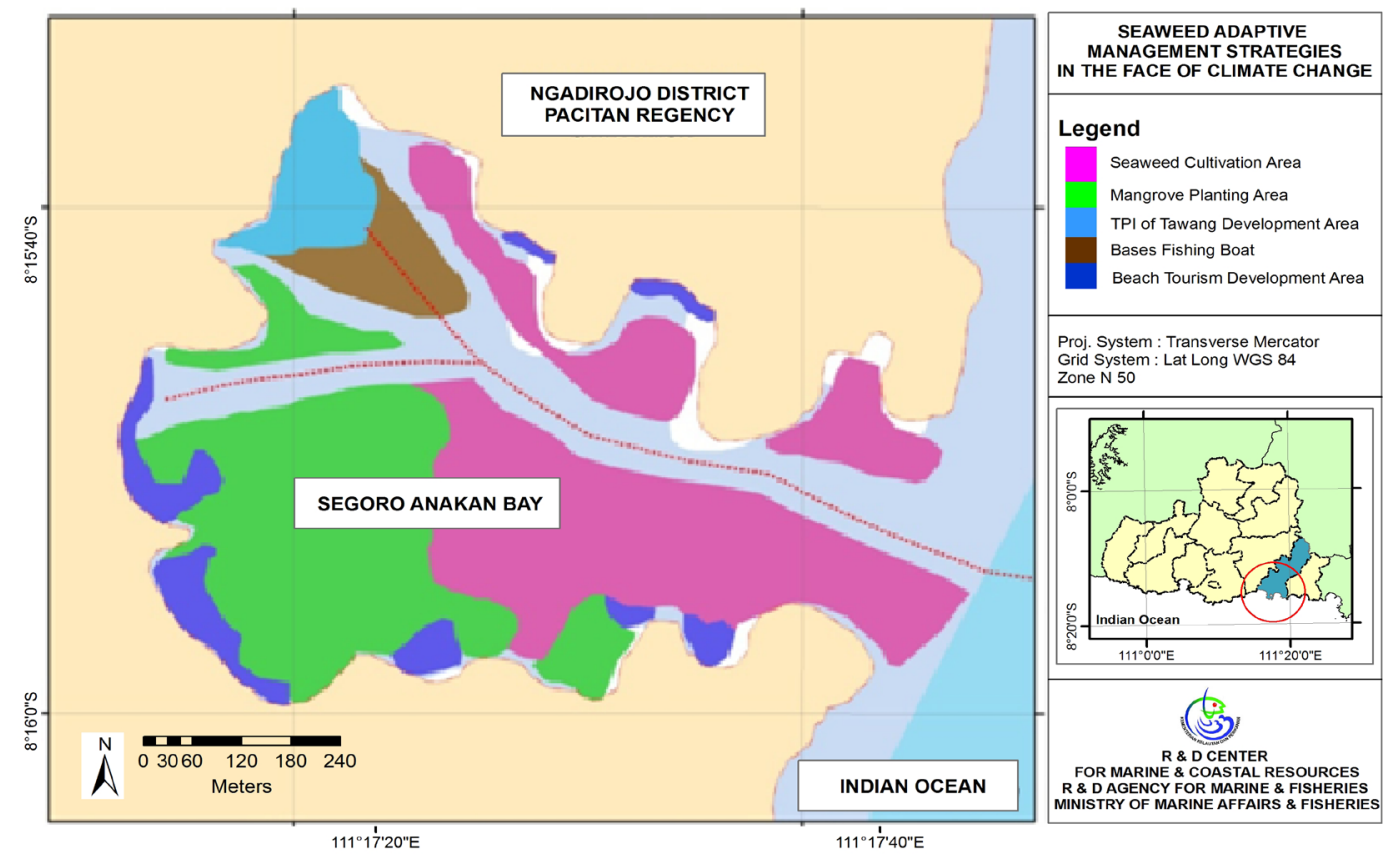

Figure 7. Recommendation Map of Spatial Adaptation to Climate Change Impacts in of Segoro Anakan Bay, Sidomulyo Village, Ngadirojo District, Pacitan Regency.

Land intensification deals with the ways to increase production, in terms of not only the quantity but also the quality of production as the most important matter. The form of land intensification that can be employed is seaweed cultivation technique by applying layered off bottom method (especially in area of inner bay with height of $100 \mathrm{~cm}$ measured from the bottom water as well as with basic substrates of sand and rubble). In more open area of bay, where the substrates comprise rocks, the planting system that can be applied is bottom system, in which the seaweed seeds are tied up to the coral reefs, and then they are spread to the bottom water. The method is relatively easy but rarely used because of some drawbacks. One of them is that many seedlings are swept by waves. Thus, seed spreader engineering is required. One of spreading systems/ tools being tested in SegoroAnakan bay for planting in open sea areas and in substrates of rocks is a raft bottom method with circling device modification (Figure 8). This device does not necessarily need vast areas and is easily controlled, particularly in the area with extreme waves and streams, like SegoroAnakan bay. 


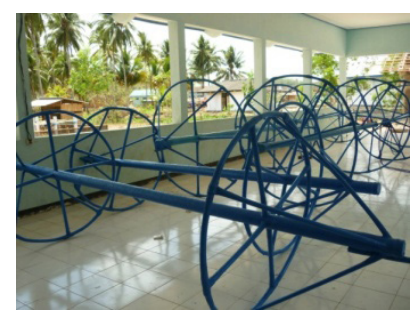

a)

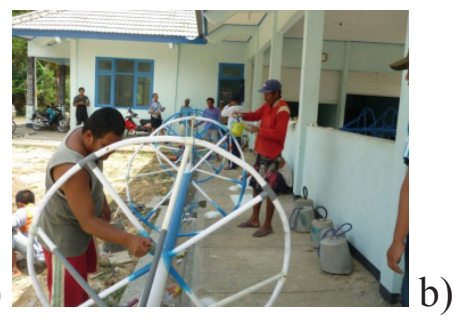

Figure8. The Raft Bottom Method with Circling Device Modification

\section{Adaption Scenario 2: Land Conversion}

Affected areas become areas that are difficult to be developed and are relatively no longer productive as locations for sea cultivation; and therefore, one of scenarios to do is to converse the land use in the form of land recovery by planting mangroves in the affected areas. Mangroves can be a highly important chainlink for maintaining the ecological balance of a certain water area and they also play important role in climate change mitigation by absorbing carbon/ $\mathrm{CO}_{2}$ emission. Mangrove response to the increase of $\mathrm{CO}_{2}$ concentration in the atmosphere has been empirically proven by Farnsworth et. al. (1996) reporting that one-year-old Rhizopora mangle seedlings planted with high $\mathrm{CO}_{2}$ concentration (doubleambient, $700 \mu$ L.L-1) show greater biomasses, longer stems, more branches, and broader leaves than those planted with ambient $\mathrm{CO}_{2}$ concentration (350 $\mu$ L.L-1). Snedaker and
Araujo (1998) report that four types of Florida mangroves show responses of the decreases of stomata conductance and transpiration, and the increases of photosynthesis pace, water usage efficiency and growth pace at high $\mathrm{CO}_{2}$ concentration. Moreover, mangroves provide direct benefits to people, providing firewood, construction materials, medicinal plants, and so on. As well, mangrove can be an area in which people can find mangrove crabs, and it is effective for coastal physical protection from southern sea waves and streams. Istiyanto et al. (2003) suggest that the existence of mangroves along coastal areas can minimize the effect of tsunami wave attacking the areas. Mazda \&Wolanski (1997) and Mazda \& Magi (1997) add that mangrove vegetation, particularly the roots, have the ability to damp wave energy by reducing wave height when traveling across mangroves.

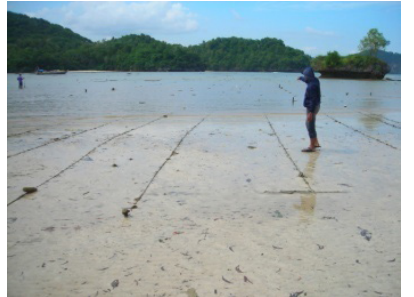

a)

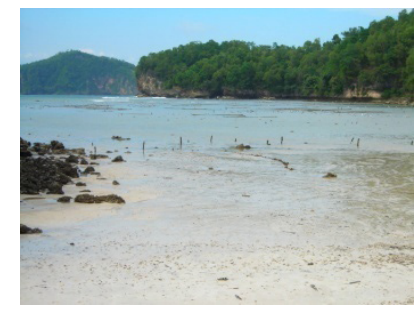

b)

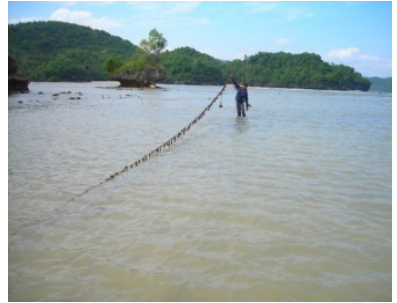

c)

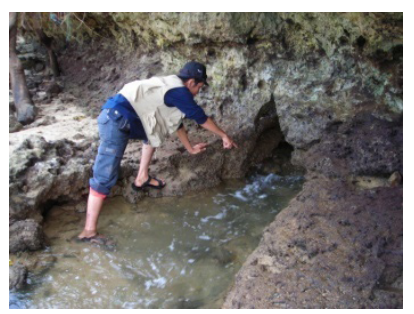

d)

Figure 9. Affected area for seaweed cultivation and it is also good for planting mangrove (a and b), and Silting in the affected area with high temperature and turbidity (c), freshwater springs that flow into the affected bay (d).

Land conversion to area of mangrove forests can also be typical new destination on tourism sector when in Pacitan. Diversification of function of mangrove forests as ecotourism will succeed if mangrove planting is continually done with proper planting pattern and technique (Mulyadi et al., 2013). In reference to measurement of water quality and substrate condition on affected areas, mangroves are suitable to grow (Figure 9 and 10). Type of mangrove vegetation which fits to the affected areas is Rhizophora $s p$. It's showed by the species of mangrove that has grown in the location. 
Adaptation Scenario 3: Combination of 1 and 2 as area of tourism concept

Area of SegoroAnakan bay is settlement and boatyard for about 300 fishermen, TPI (Fish Auction) and area of sea cultivation. It is included as affected area of climate change and tectonics. The two aforementioned scenarios can be an effective solution. Moreover, if combined, they can be alternative to create a strong village both in terms of its economic democracy and its ability in encountering impacts of the climate change. Tourism concept is defined as concept of coastal zone development combining fishery and tourism potentials. It is proved to be able to increase people's economy without sacrificing their main activity working as farmers or fishermen. In addition, this concept successfully protects the existing environments and resources.

\section{Adaptation Scenario 4: Alternative Livelihood}

One of climate change impacts is long drought which can be one of causes of seaweed harvest failure. Temperature is the key factor in marine environment since it has universal influence and commonly becomes limiting factor of growth (Odum, 1993). According to Lunning (1990), optimum temperature for growth of algae in tropical areas is $15^{\circ} \mathrm{C}-30^{\circ} \mathrm{C}$. Van Den Hoek (1995) states that the extreme temperature change leads to seaweed's death, reproduction phase disturbance and growth inhibition. Furthermore, the high temperature increase results in pale yellowish thallus of seaweed. This causes the seaweed to be unable to grow well (Luning, 1990).

Besides, dry season also brings about jellyfish boom along the waters of Pacitan. Long drought makes temperature of sea water cold. The jellyfish, hence, tend to move to the shore. However, in coastal zone of Pacitan, fishermen specifically in SegoroAnakanbay in Ngadirojo sub-district consider that this condition is a blessing. Since the entrance of jellyfish suppliers, fishermen catch jellyfish to be sold to them (Figure 10). This opportunity should be enhanced. That is why government plays important role to provide complete infrastructure information service and invite required investors.
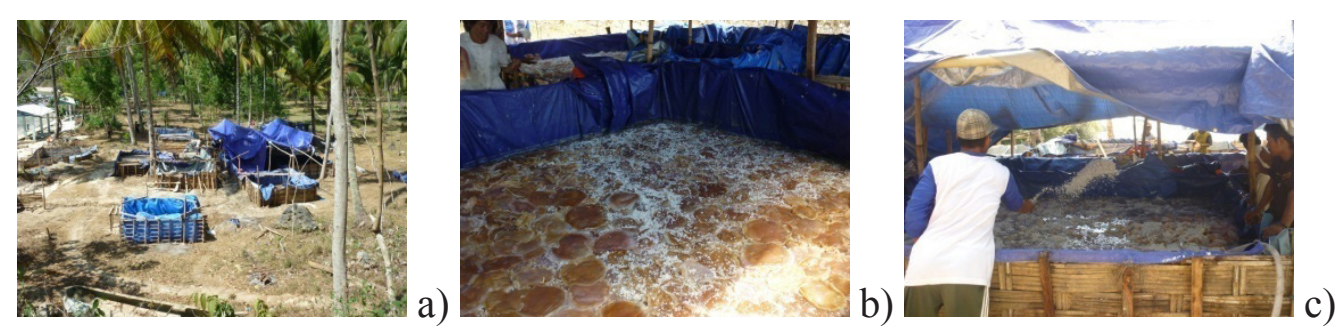

Figure 10. Jellyfish Storage (a and b), The Process of Salting Jellyfish to Sell to Collectors(c).

\section{Conclusion}

Base on the interpretation of the landsat imagery multi-temporal $(2002-2011)$ by using Lysenga Algoritm, it has been a land cover change. The land cover change has been indicated as the impact of the climate change phenomenon. The impact of the climate change give particular impacts to the area and production of seaweed farming. The solution is adaptation scenario. The adaptation scenarios that can be implemented include intensification and extension of land, land conversion, alternative livehood, and fishing tourism as a combination of those three previous scenarios.

\section{References}

Adger, Neil, Maria Brockhaus, Carol J. Pierce Colfer and Brent Sohnger. 2009. FutureSocioEconomic Impacts and Vulnerabilities dalam Adaptation of Forests and People to Climate Change (Risto Seppala, Alexander Buck, Pia Katila, editor). IUFRO World Series Vol. 22. 
Adger.W.N., Agrawala, S., Mirza, M.M.Q., Conde, C., Oe Brien, K., Pulhin, J., Pulwarty, R., Smit, B. and Takahashi, K. 2007. Assessment of Adaptation Practices, Options, Constraints and Capacity. In: Parry, M.L., Canziani, O.F., Palutikof, J.P., van derLinden, P.J. and Hanson, C.E. (eds.). Climate Change 2007: Impacts, Adaptation and Vulnerability. Contribution of Working Group II to the Fourth Assessment Report of the Intergovernmental Panel of Climate Change (IPCC).Cambridge University Press,Cambridge, UK. P. 717-743.

Arifin, T, R. Boharidan I.S. Arlyza. 2014. AnalisisKesesuaianRuangBerbasisBudidayaLaut diPulau-Pulau Kecil Makassar: AplikasiSistemInformasiGeografis. Forum Geografi, Vol. 28, No. 1, Juli 2014: 91 - 102.

Dale, V. 1997. The Relationship Between Land-Use Change and Climate Change. Ecological Application 7 (30): 753-769.

Dinas Kelautan dan Perikanan Kabupaten Pacitan. 2012. Laporan Tahunan Dinas Kelautan dan Perikanan Kabupaten Pacitan.

Farnsworth, E. J. and A. M. Ellison. 1996. Sun-Shade Adaptability of the Red Mangrove, Rhizophora Mangle (Rhizophoraceae): Changes Through Ontogeny at Several Levels of Biological Organisation. Amer. J. Bot. 83: 1131-1143.

Hertanto, 2011. Sesar Grindulu Pacitan dalam Status Waspada. Posting Blogging Nopember 2011. http://geoenviron.blogspot.com/2011/11/. Diakses tanggal 18 Desember 2011.

IPCC. 2007. Summary for Policy Makers. Climate Change 2007: Impacts, Adaptation and Vulnerability. Contribution of Working Group II to the Fourth Assessment Report of the Intergovernmental Panel for Climate Change (IPCC). Parry, M.L., Canziani, O.F., Palutikof, J.P., van der Linden, P.J. dan Hanson, C.E. (eds.). Cambridge University Press, Cambridge, U.K., p. $7-22$.

Istiyanto, D.C., S.K. Utomo, dan Suranto. 2003. Pengaruh Rumpun Bakau terhadap Perambatan Tsunami di Pantai. Makalah pada Seminar Nasional "Mengurangi Dampak Tsunami: Kemungkinan Penerapan Hasil Riset” di Yogyakarta, 11 Maret 2003.

Jadmiko, SD. 2011. Proyeksi Perubahan Iklim Berdasarkan Hasil Keluaran Model Iklim Regional (Studi Kasus: Kabupaten Indramayu dan Kabupaten Pacitan). Skripsi. Departemen Geofisika dan Meteorologi, Fakultas MIPA, IPB. Bogor.

Jaya, I Nengah Surati. 2009. Analisis Citra Dijital: Perspektif Penginderaan Jauh Untuk Pengelolaan Sumberdaya Alam. Fakultas Kehutanan IPB. Bogor.

Lillesand, T.M. \& Kiefer, R.W. 1990. Penginderaan Jauh dan Interpretasi Citra (Terjemahan Dulbahri, dkk), Gadjah Mada University Press.

Luning., 1990. Seaweeds, Their Environment Biogeography and Ecophysiology.John Wiley and Sons. New York.

Mazda, Y. and E. Wolanski. 1997. Drag Force Due to Vegetation in Mangrove Swamp. Mangrove and Salt Marches. Kluwer Academic Publisher, Netherland.

Mazda, Y. and M. Magi. 1997. Mangrove Coastal Protection From Waves in the Tong King Delta, Vietnam. Kluwer Academic Publisher, Netherland.

Moediarta, R dan P. Stalker. 2007. Sisilain Perubahan Iklim Mengapa Indonesia Harus Beradaptasi untuk Melindungi Rakyat Miskinnya. United Nations Development Programme Indonesia. 
Mulyadi E., O. Hendriyanto, dan N. Fitriani. 20013. Konservasi Hutan Mangrove Sebagai Ekowisata. Jurnal Ilmiah Teknik Lingkungan Vol.1 Edisi Khusus.

Odum, E.P. 1993. Dasar-Dasar Ekologi. Edisi Ketiga. Gajah Mada University Press. Jogjakarta. H. 134-162.

Purwadhi, F.S.H. 2001. Interpretasi Citra Digital.Grasindo. Jakarta.

Roessig, J.M.; C.M. Woodley; J.J. CechJR and L.J. Hansen. 2004. Effects of Global Climate Change on Marine and Estuarine Fishes and Fisheries. Reviewsin Fish Biology and Fisheries 14:251-275.

Schowengerdt, R.A., 2007. Remote Sensing Models and Methods for Image Processing. Third Edition. Elsevier. London.

Snedaker, S. C. and R. J. Araujo. 1998. Stomatal Conductance and Gas Exchange in Four Species of Caribbean Mangroves Exposed to Ambient and Increased CO2. Mar. Freshw. Res. 49: 325-327.

Van Den Hoek, C., D.G. Mann and H.M. Johns. 1995. An Introduction to Phycology. Cambridge at the University Press. London. 

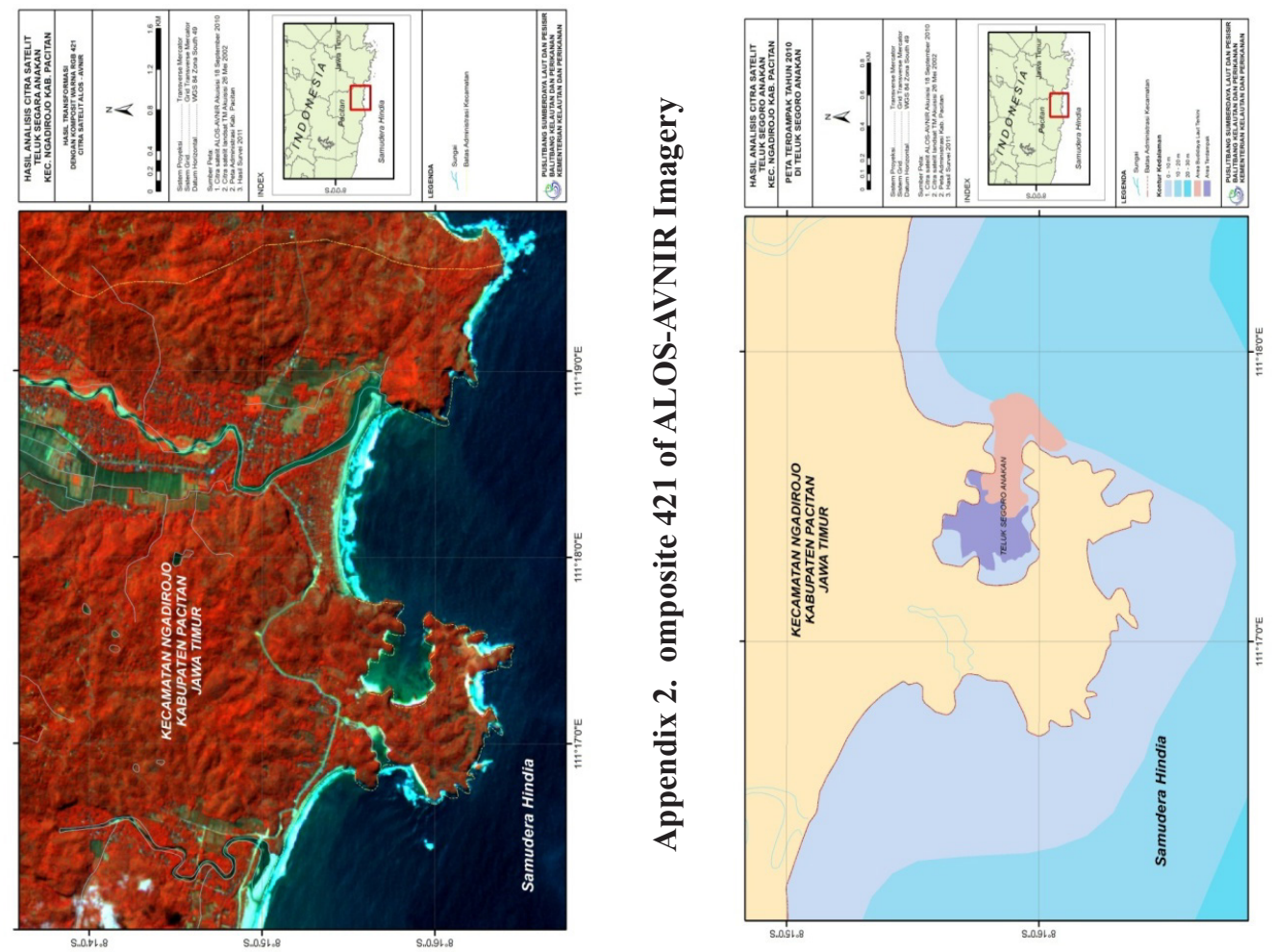

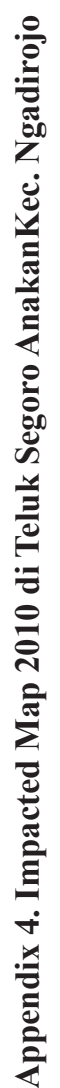
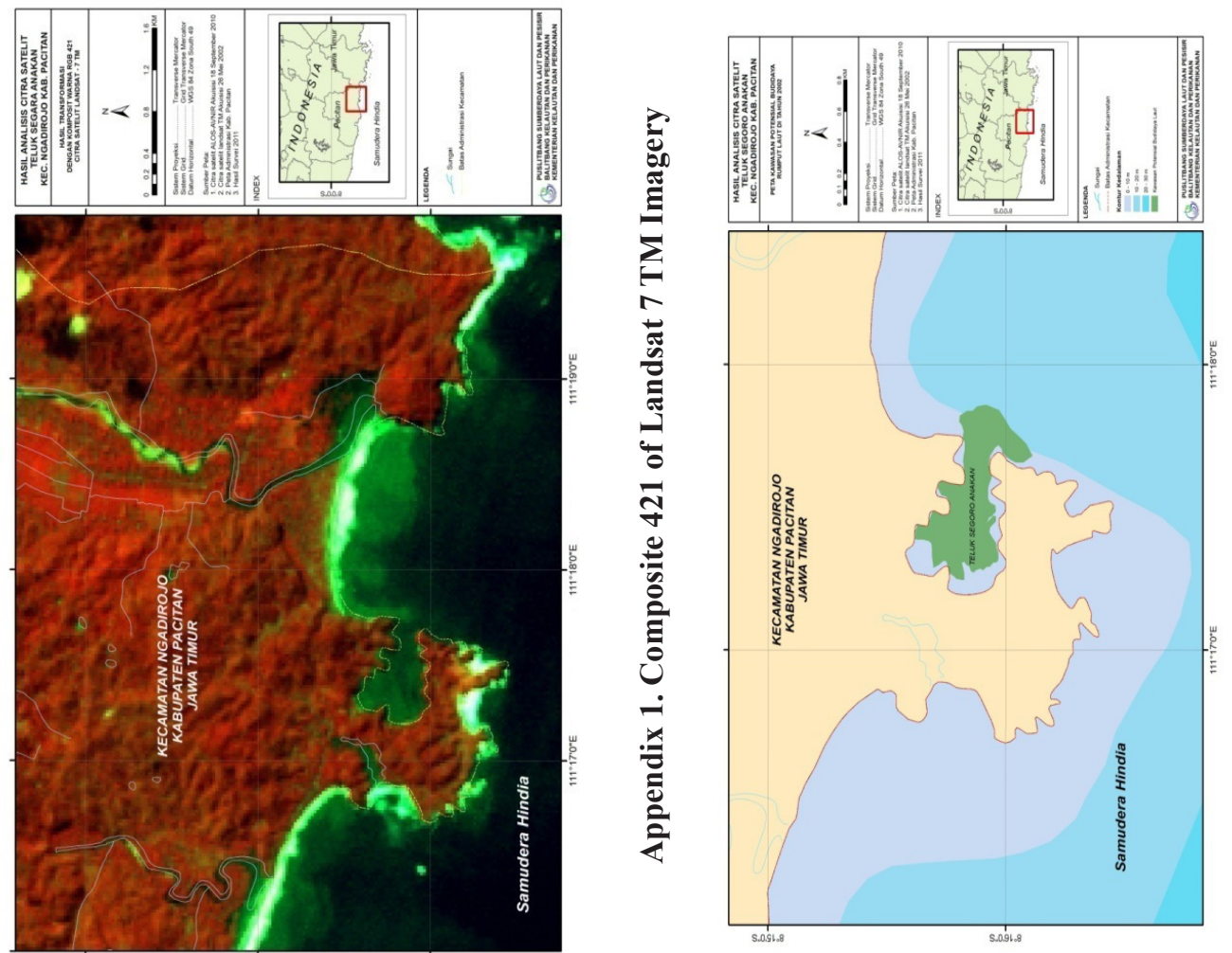

ठ̊. 